\title{
Relacja żony Leona Feldhendlera
}

Przechowywana w archiwum Yad Vashem relacja, opatrzona sygnaturą 0-16/464, jest $\mathrm{z}$ wielu powodów dokumentem niezwykłym. Spisana została w Lublinie w grudniu 1945 r. przez żonę Leona Feldhendlera, jednego z dwóch przywódców powstania w obozie śmierci w Sobiborze. Relacji nie nadano tytułu, a jej autorka nie podała nawet swoich danych personalnych. $\mathrm{Z}$ odręcznego dopisku umieszczonego na ostatniej stronie rękopisu dowiadujemy się, że jest to „zeznanie wdowy po Feldhendlerze”, która „ma obecnie 20 lat życia”. Również sama relacja przynosi niewiele informacji pozwalających na bliższą charakterystykę jej autorki. Wiadomo, że latem 1944 r. pojawiła się w wyzwolonym Lublinie, gdzie spotkała przyszłego męża, którego znała jeszcze sprzed wojny. Ich ślub - jak czytamy - był „w zimie zeszłego roku”, natomiast „pięć tygodni i trzy dni” później związek zakończyła tragiczna śmierć Feldhendlera. W swoich wspomnieniach o obozie zagłady w Sobiborze Tomasz Blatt podaje, że nazwisko żony przywódcy powstania brzmiało Perlmutter i że pochodziła ona $z$ Krasnegostawu ${ }^{1}$. Niestety, w zachowanych imiennych rejestrach ocalałych Żydów, sporządzonych przez Wojewódzki Komitet Żydów w Lublinie, brak osoby o takim nazwisku pochodzącej z tego właśnie miasteczka. Nie wgłębiając się jednak w biograficzne niuanse, większość badaczy wykorzystujących przytoczony dalej przekaz w swoich publikacjach określa go po prostu mianem „Relacji żony Feldhendlera"2.

Anonimowość autorki wynika z prostej przyczyny - nie jest ona główną bohaterką swoich wspomnień. Relacja dotyczy wojennych i tużpowojennych losów jej męża - od prezesury w żółkiewskim Judenracie, przez koszmar obozu w Sobiborze, bunt więźniów, ukrywanie się po stronie aryjskiej i partyzantkę, po śmierć z nieznanej ręki w powojennym Lublinie. Jak pisząca sama zaznacza: „Historię tę opowiedziałam za Niego, ja, żona jego, po dziewięciu miesiącach jego nieobecności”. W zasadniczej części relacji mamy więc do czynienia z przekazem niejako z dru-

${ }^{1}$ Thomas Toivi Blatt, Sobibór. Zapomniane powstanie, tłum. Dorota Szczygieł, WłodawaChełm: Muzeum Pojezierza Łęczyńsko-Włodawskiego, [2003], s. 159. Według Blatta (relacja ustna złożona autorom opracowania) Perlmutter była wcześniej związana z zamordowanym w listopadzie 1944 r. w Lublinie innym byłym więźniem Sobiboru, Herszem Blankiem.

${ }^{2}$ Por. Yitzhak Arad, Belzec, Sobibor, Treblinka: The Operation Reinhard Death Camps, Bloomington: Indiana University Press, 1999, s. 422. 
giej ręki, podobnym pod tym względem do przypadku zamordowanego w $1946 \mathrm{r}$. w Lublinie Chaima Hirszmana, ocalałego z obozu zagłady w Bełżcu, którego relację po jego śmierci kontynuowała żona Pola ${ }^{3}$.

Głównym źródłem informacji o okupacyjnych przeżyciach Feldhendlera były opowieści jego samego (każde spotkanie z przyszłym mężem, jak czytamy, „równało się pogawędce o Sobiborze”). Bezpośrednim przekazem autorki jest natomiast przedstawienie powojennych losów głównego bohatera jej wspomnień, w tym przejmujący opis zamachu na jego życie.

Nie wszystkie informacje podawane przez autorkę relacji pokrywają się ze wspomnieniami spisanymi przez samego Leona Feldhendlera ${ }^{4}$. Relacja przywódcy powstania w Sobiborze wydaje się bardziej stonowana i mniej emocjonalna. Jest w niej sporo faktów, które umiejscowione są w czasie. Mimo że Feldhendler opisuje okrucieństwa, jakich się dopuszczali niemieccy członkowie załogi obozowej wobec deportowanych do obozu Żydów czy osadzonych już więźniów żydowskich, w jego opisie nie są one aż tak wyrafinowane, jak w relacji jego żony. Być może jest to podkoloryzowanie całej opowieści dokonane przez jej autorkę. Bez wątpienia druga żona Feldhendlera nie wiedziała, że w Sobiborze stracił on pierwszą małżonkę oraz dwoje dzieci. W relacji Feldhendlerowej jest mowa o siostrze, szwagrze i ich dzieciach. Możliwe, że Leon Feldhendler nie opowiedział drugiej żonie o swoim wcześniejszym małżeństwie. Ogólnie można stwierdzić, że relacja Feldhendlerowej w warstwie dotyczącej obozu w Sobiborze pokrywa się ze wspomnieniami jej męża, chociaż niewątpliwie o wielu szczegółach autorka nie wiedziała lub mogła je zniekształcić.

Sprostowań i uzupełnień wymagają również przedwojenne losy Feldhendlera oraz w okresie 1943-1945. Lejb (Leon) Feldhendler urodził się w Turobinie 1 czerwca 1910 r. ${ }^{5}$ Rok później rodzina przeniosła się do Żółkiewki, gdzie jego ojciec Symcha Feldhendler (ur. 1876 w Turobinie) objął posadę głównego rabina. W latach trzydziestych młody Feldhendler zajmował się handlem zbożem oraz dzierżawił miejscowy tartak. Jak wskazują w swoich świadectwach zdeponowanych w Yad Vashem dwie przedwojenne mieszkanki Żółkiewki, Mila Szternzys i Guta Zylbersztajn, Leon Feldhendler poślubił przed wojną Tobę, urodzoną w 1917 r. córkę żółkiewskiego kupca Lejba Wajnberga, z którą prawdopodobnie

\footnotetext{
${ }^{3}$ Archiwum Żydowskiego Instytutu Historycznego (dalej AŻIH), 301/1476, Relacja Chaima Hirszmana i zeznanie Poli Hirszman.

${ }^{4}$ Leon Feldhendler złożył swoją relację przed marcem 1945 r. w lubelskim oddziale Centralnej Żydowskiej Komisji Historycznej. Dzisiaj część tej relacji przechowywana jest w AŻIH pod sygnaturą 301/72. Jest to zaledwie fragment wspomnienia, obejmujący okres od września 1939 r. do momentu deportacji Feldhendlera z Izbicy do obozu zagłady w Sobiborze, co nastąpiło 2 XI 1942 r. Część poświęcona samemu obozowi zagłady, której nie ma w oryginale, opublikowana została w 1946 r. w: Dokumenty i materiały z czasów okupacji niemieckiej $w$ Polsce, t. 1: Obozy, red. Nachman Blumental, Łódź: Centralna Żydowska Komisja Historyczna, 1946, s. 202-207.

${ }^{5}$ AŻIH, Żydowska Samopomoc Społeczna, 211/607, k. 15.
} 
miał dwóch synów ${ }^{6}$. Zarówno żona, jak i dzieci zginęły w Sobiborze. Można przypuszczać, że pojawiające się w relacji jego drugiej żony informacje o deportowanych wraz z Feldhendlerem do Sobiboru członkach jego rodziny (siostra, szwagier i ich synek) dotyczą w rzeczywistości właśnie ich. Przed 1939 r. Feldhendler nie brał aktywnego udziału w życiu społecznym i politycznym żółkiewskich Żydów, zajmując się przede wszystkim działalnością handlową. „Wybicie się na stanowisko prezesa Judenratu” - jak to ujmuje jego druga żona - Feldhendler zawdzięczał prawdopodobnie silnej pozycji jego ojca oraz ucieczce z miasteczka na obszary zajęte przez Sowietów wielu dotychczasowych przywódców żydowskiej społeczności Żółkiewki.

Po udanej ucieczce z obozu w Sobiborze razem z innym uciekinierem z obozu, pochodzącym z Hrubieszowa Majerem Zissem („Majorkiem”), oraz zbiegiem z getta w Izbicy Moszkiem Honigiem znalazł schronienie w gospodarstwie rodzeństwa Jana i Katarzyny Wielebów w położonym niedaleko Żółkiewki Maciejowie Starym. Po kilku miesiącach cała trójka przeniosła się do kolejnej kryjówki w tej samej wsi, przygotowanej przez Piotra i Stefanię Sadłów, gdzie doczekała się wkroczenia Armii Czerwonej (w zachowanych źródłach archiwalnych brakuje potwierdzenia, że Feldhendler brał udział w działaniach partyzanckich, o czym mówi relacja).

Latem 1944 r., po przybyciu do Lublina, Feldhendler początkowo zamieszkał wraz z innymi ocalałymi uciekinierami z Sobiboru w kamienicy przy ul. Kowalskiej 4. Zajął się prowadzeniem różnych interesów handlowych, a po pewnym czasie uruchomił w dzielnicy Kalinowszczyna garbarnię, w której znalazło zatrudnienie wielu ocalałych z wojny Żydów. Prawdopodobnie już po ślubie przeniósł się z mieszkania przy ul. Kowalskiej do nowego, samodzielnego lokum przy Złotej 6/4. Właśnie tam 3 kwietnia 1945 r. wydarzyła się tragedia - Feldhendler został postrzelony przez nieznanych sprawców. Zmarł po trzech dniach, 6 kwietnia, na oddziale chirurgicznym Szpitala im. Wincentego à Paulo? .

Opublikowana tu relacja Feldhendlerowej może być traktowana jako zapis jej emocji, związanych przede wszystkim z tragiczną śmiercią męża. Jest ona też źródłem pozwalającym ustalić, w jaki sposób autorka zapamiętała opowieści Leona Feldhendlera. Czy on sam je koloryzował - można w to raczej wątpić. Niewątpliwie cenne informacje uzyskujemy z listów, jakie pozostawały w jej posiadaniu. Jeden został napisany przez deportowanych do Sobiboru ostatnich więźniów żydowskich z obozu zagłady w Bełżcu, drugi zaś jest prawdopodobnie fragmentem odezwy przygotowanej na moment wybuchu powstania w Sobiborze.

Można jedynie wyrazić ubolewanie, że autorka relacji tak mało napisała o sobie $^{8}$. Język jej wspomnień może wskazywać na osobę inteligentną, która zapewne

${ }^{6}$ Yad Vashem, The Central Database of Shoah Victims' Names (http://www.yadvashem. org/wps/portal/IY_HON_Welcome).

${ }^{7}$ Adam Kopciowski, Zajścia antyżydowskie na Lubelszczyźnie w pierwszych latach po drugiej wojnie światowej, „Zagłada Żydów. Studia i Materiały” 2005, nr 3, s. 191-192.

${ }^{8}$ Feldhendlerowa zmarła w domu opieki społecznej w Izraelu; pod koniec życia chorowała na jakąś chorobę psychiczną. Informacja uzyskana przez autorów od Tomasza Blatta. 
ukończyła szkołę powszechną, a podany przez nią wiek wskazuje, że nie zdążyła już wstąpić do gimnazjum. Z pewnością sprawnie posługiwała się językiem polskim, a nawet starała się stworzyć tekst literacki. Zdając sobie sprawę, że nie wszystkie informacje podawane przez Feldhendlerową są zgodne $z$ faktami znanymi z dziejów obozu w Sobiborze, nawet tymi, które zamieścił sam Leon Feldhendler we własnych wspomnieniach, opatrzyliśmy jej wspomnienia przypisami, które korygują niektóre szczegóły. Zachowaliśmy także pisownię oryginału, uwspółcześniliśmy jedynie interpunkcję. 


\section{Relacja żony Leona Feldhendlera (Archiwum Yad Vashem, 0-16/464)}

Lublin 12 XII 1945 r.

Leon Feldhendler, urodzony w Żółkiewce w 1915 r. ${ }^{1}$ Syn rabina. Bardzo zdolny. Uczył się u Ojca i nauczycieli z zakresu szkoły powszechnej i średniej. Podczas wojny jako bardzo zaradny i lubiany „wybił się” na stanowisko prezesa Juden-Ratu. Prosiło Go o to miasto, a zmusił, przekonując o tej konieczności, czczony przez Niego Rabin - Ojciec. Prowadząc Go ku ogólnemu zadowoleniu całego miasta, starał się pomagać i ratować mieszkańców, wyciągając Ich z obozów, Bełżca² ${ }^{2}$ który początkowo był obozem pracy i gdzie wyznaczono młodzież na pracę, następnie Rudy ${ }^{3}$ i Majdanek ${ }^{4}$. Kilkakrotnie płacili kontrybucje za zezwolenie pozostania na miejscu. Sytuacja ta trwała do 1941 r. Wtedy zaczęto do miasta tego przysyłać wysiedleńców z Poznańskiego, z Koła, Poznania, Konina, Kalisza. Ludzi tych umieszczano w mieszkaniach miejscowych obywateli, gdzie razem gnieżdżono się, a Juden-Rat starał się jako tako Im pomóc. I tak toczyło się to wszystko, przeplatane łapankami do obozów, przyjeżdżaniem okolicznego niemca, postracha całej ludności, który nie mógł wyżyć dnia bez widoku krwi. Engels ${ }^{5}$. Człowiek-zwierzę, z ogromną, niespotykanie wielką czaszką, chwytający dzieci za włosy i strzelający do Nich. W nocy wpadał do mieszkań, strzelał, czasami szukał kobiet, którym kazał rozbierać się do naga, po tym kładł na stół i bił, dopóki ofiara przestała reagować, nie mówiąc już ani słowa, co też przestało mu dawać satysfakcję i pozostawiał, najczęściej nieuleczalną już swemu losowi.

Aż w 1941 r., pod koniec, ktoś otrzymuje list z Koła, że pozostała ludność w mieście jest wywożona do obozu, gdzie jest krzesło elektryczne i gazy, i skąd nikt już się żywy nie wydostaje (uciekło dwóch chłopców, którzy początkowo zakopywali trupy ${ }^{6}$. Wszyscy drżą. Ale nie wierzą. To niemożliwe.

Na wiosnę 1942 r. wysiedlenie z Lublina?. Podobno na Ukrainę. Do obozów, gdzie uprawiają ziemię, gdzie są warsztaty pracy. Zresztą różne wersje. Aż zaczynają

${ }^{1}$ W rzeczywistości urodził się w Turobinie w $1910 \mathrm{r}$.

${ }^{2}$ Obóz pracy przymusowej dla Żydów, Romów i Sintich w Bełżcu funkcjonował od kwietnia do listopada $1940 \mathrm{r}$.

${ }^{3}$ Chodzi o obóz pracy przymusowej dla Żydów w Rudzie-Opalin koło Chełma.

${ }^{4} \mathrm{~W}$ tym czasie obóz koncentracyjny na Majdanku jeszcze nie istniał. Powstał dopiero jesienią $1941 \mathrm{r}$. z przeznaczeniem pierwotnie dla jeńców sowieckich.

${ }^{5}$ Kurt Engels - kierownik placówki SD i Policji Bezpieczeństwa na powiat krasnostawski, który na swoją siedzibę obrał Izbicę - największe skupisko żydowskie w powiecie. Engels znany był z okrucieństwa zarówno w stosunku do Żydów, jak i Polaków.

${ }^{6}$ Chodzi o obóz zagłady Kulmhof am Ner, gdzie w rzeczywistości Niemcy mordowali Żydów w specjalnych samochodach przebudowanych na komory gazowe.

${ }^{7}$ Deportacje z getta lubelskiego do obozu zagłady w Bełżcu rozpoczęły się w nocy z 16 na 17 III $1942 \mathrm{r}$. 
się wysiedlenia i w tym mieście. Ludność początkowo zostaje naznaczana przez Juden-Rat, zgłasza się i jedzie do pracy. Po pierwszym transporcie ktoś, jakiś Polak wraca i opowiada, że spotkał tego znajomego, wygląda źle, widział Go pracującego na roli. Jest obdarty, rozmawiał z Nim, jest smutny ${ }^{8}$. I za przykładem tego szli inni, zaczęli opowiadać historie w celu wyłudzenia pieniędzy na przywiezienie listu (Żydom pociągiem, a później w ogóle poruszać się nie wolno było, ostatnio nawet poza obrębem miasta spotkanego Żyda rozstrzeliwali). I trwał przez pewien czas okres Jego niezdecydowania i niepokoju. Aż po późniejszym wysiedleniu wrócili dwaj chłopcy, opowiadając szczegółowo o gazowaniu i zakopywaniu trupów w dołach, które Żydzi kiedyś zrobili jako okopy9 ${ }^{9}$ I ludność przemyśliwała nad ulepszeniem kryjówek (bo i przed tym były, ale tylko dla mężczyzn ukrywających się przed łapankami do obozów i strzelaniem). Teraz musiały one pomieścić całe rodziny i zapas kilkudniowy dla Nich. Po tym wysiedlenie następowało po wysiedleniu, coraz mniej było Żydów, coraz bardziej ciągnęli uprzywilejowanych. On, prezes, stoi zawsze na placu, stoi zawsze oko w oko z tymi bandytami, którzy patrzeć nie mogli na Jego wysoką, silnie zbudowaną postać. Zwymyślali Go więc i bili, nieraz obrywał od Niemca, którego karmił łapówkami i który zwał Go swym przyjacielem.

Aż nadeszła dawno opłacana, by ją odwlec, ostateczna wysyłka reszty osób do Izbicy $^{10}$. Tu czuło się, że jest bardzo źle. Ludzi bowiem było tyle, iż nie mówiąc już o mieszkaniu, na ulicy się pomieścić nie mogli. Przechodząc, słyszało się języki całej Europy ${ }^{11}$. Lecz któż zwracał wtedy na to uwagę? Szukało się sposobu, już nie pozostania, ale chociażby pozostania ostatnim. I wtedy On pojechał do Lublina, do niemców, którzy prowadzili tę akcję, do Globocnika, majora ${ }^{12}$, zawożąc złoty zegar,

\footnotetext{
${ }^{8}$ Pierwsza akcja w Żółkiewce nastąpiła w dniach 12-15 V 1942 r. Około 1000 Żydów zostało wówczas wysiedlonych do Krasnegostawu, skąd po selekcji większość deportowano wraz z tysiącami Żydów z całego powiatu do obozu zagłady w Sobiborze. Kilkuset młodych mężczyzn po selekcji w Krasnymstawie wywieziono do obozu koncentracyjnego na Majdanku.

${ }^{9}$ Prawdopodobnie chodzi o obóz zagłady w Bełżcu (choć większość opracowań podaje, że Żydzi z Żółkiewki zostali deportowani tylko do Sobiboru), gdzie jeden z masowych grobów zlokalizowano we fragmencie rowu przeciwczołgowego, kopanego przez więźniów żydowskich jeszcze w 1940 r., gdy funkcjonował tam obóz pracy. „Późniejsze wysiedlenie” - chodzi tu prawdopodobnie o akcję z 10 VIII 1942 r., kiedy to z Żółkiewki deportowano kilkuset Żydów. Tatiana Berenstein, Martyrologia, opór i zagłada ludności żydowskiej w dystrykcie lubelskim, „Biuletyn ŻIH” 1957, nr 21, s. 72.

${ }^{10}$ Nastapiło to 16 X 1942 r.

${ }^{11}$ Od marca do listopada 1942 r. Izbica nad Wieprzem pełniła funkcję największego getta tranzytowego w dystrykcie lubelskim. Przeszło przez nie około 24000 Żydów polskich, czeskich, słowackich, niemieckich i austriackich. Robert Kuwałek, Getta tranzytowe w dystrykcie lubelskim [w:] Akcja Reinhardt. Zagłada Żydów w Generalnym Gubernatorstwie, red. Dariusz Libionka, Warszawa: IPN, 2004.

${ }^{12}$ Odilo Globocnik - dowódca SS i Policji Bezpieczeństwa w dystrykcie lubelskim w latach 1939-1943. W SS miał stopień generała (SS-Obergruppenführer). W latach 1942-1943 był odpowiedzialny za organizację zagłady Żydów w GG w ramach akcji „Reinhardt”. Jest nieprawdopodobne, by Leon Feldhendler uzyskał pozwolenie na osobiste spotkanie z Globocnikiem. Być może chodziło o jakiegoś niższego funkcją oficera SS ze sztabu Globocnika.
} 
złotą bransoletę wysadzaną brylantami i inne kosztowne rzeczy, prosząc o pozostawienie Żółkiewki. Otrzymał przyrzeczenie. I kiedy nastąpiło ogólne, szczególnie srogie wezwanie do zebrania się na placu, gdzie otrzyma się karty pozostania, wyciągnął swych najbliższych, Matkę i Ojca, i licząc na wypuszczenie jeszcze trochę Jego ludzi, wyprowadził Ich na plac. Gestapowcy, przechadzając się po zgromadzonym tłumie, strzelali weń, zabijając niektóre osoby. A później nastąpiła selekcja. Ludzi potrzebnych im stawiali po jednej stronie, a drugą grupę po drugiej obok pociągu. On został przesłany na drugą stronę, do grupy potrzebnych im. Lecz przybiegł z powrotem, nie chcąc pozostawić rodziców. Wówczas to Niemcy, obracając się w tłumie i strzelając, zabili Mu Ojca i Matkę. Został przy Nich. Ludzi ładowano do wagonów.

Gestapowiec zauważył Go i nie ruszył, poznając. Wysiedlenie skończyło się. Własnymi rękoma ułożył trupy ukochanych, najgodniejszych poważania rodziców na furmankę, sam wykopał dół i zakopał Ich, musząc dalej żyć dla i z bratem i siostrą, którzy nie chcąc Go usłuchać, nie wyszli na plac. I znów po paru dniach wysiedlenie (było to w październiku) ${ }^{13}$. Tym razem nic już nie pomogło, gdy Go złapali, wsadzili do wagonów i wywieźli do Bełżca. Wyskoczył z pociągu. Wrócił do kryjówki, gdzie czekała, opłakując, zrozpaczona rodzina. Dla Nich też i przez Nich, w biegu, narażony na śmierć z kuli wachmanów transportu lub ludności w drodze powrotnej, nie mając już żadnej nadziei i nie chcąc, nie mając już sił żyć, wyskoczył. Lecz znów za parę dni wysiedlenie. Wykryli kryjówkę miejscowi polacy i wszyscy znaleźli się na placu. Stali w pociągu. Ludzie skakali. Dziecko prosiło Go: wyskocz Wujaszku, tyś taki zaradny, dasz sobie radę, przeżyjesz i zemścisz się za nas. Mówił mały, pięcioletni chłopaczek. Lecz nie chciał. Już nie chciał. Jechali, dusząc się, jechali, czekając pieca jak wybawienia, końca cierpień. Nareszcie z dala druty kolczaste i napis „Sobibór dwór”14. Wjeżdżają do środka. Specjalne szyny prowadzą wewnątrz. Żydzi tutaj, jakież to dziwne. Wyładowywali Ich. Ustawili w dwuszereg. Potrzeba kilkanaście osób. Żydzi wybierają, wskazując niemcom, którzy, gdy im odpowiada, stawiają na stronę. Kuzyn Jego, który ucieszył się Jego widokiem, wskazuje nań niemcom, opowiadając, że to pierwszorzędny stolarz. Wziął Go więc na stronę. Lecz On ucieka z powrotem do brata. Nie chce patrzeć i palić tę pozostałą garstkę Żydów. Niemiec, licząc, zauważył brak jednego i poznawszy Go po drugiej stronie, doszedł doń, bijąc i kopiąc na drugą stronę. Więc pozostał. Za parę godzin widział już dym z komina, gdzie palili Jego ostatnich najbliższych ludzi ${ }^{15}$. Myślał, że to może potrwa parę dni i szkoda, że musiało się zostać. Kuzyn zabrał Go do magazynu, oddając jeden dział, magazyniera w segregowaniu rozmaitych rzeczy, medykamentów i biżuterii. Na drugi też dzień znalazł

\footnotetext{
${ }^{13}$ Największa fala deportacji z Izbicy do obozów zagłady w Bełżcu i Sobiborze nastąpiła w październiku i listopadzie $1942 \mathrm{r}$.

${ }^{14} \mathrm{Na}$ bramie wjazdowej do obozu zagłady w Sobiborze znajdowała się nazwa SS-Sonderkommando Sobibor.

${ }^{15} \mathrm{~W}$ obozie zagłady w Sobiborze nie istniał budynek krematorium. Ciała zagazowanych osób palono na stosach spaleniskowych.
} 
wśród rzeczy ubrania swoich, maleńkie ubranko najmilszego małego, które położył osobno, obrączkę szwagra, pierścionek siostry ${ }^{16}$, które włożył, przyrzekając sobie nosić je do śmierci. I płynęły dnie, w których poznawał, przyzwyczajał się i zżywał z otoczeniem. Dowiedział się, że obóz jest ogrodzony naelektryzowanym drutem kolczastym ${ }^{17}$, dołami kilka metrów długości i kilka szerokości liczącymi, minami, a dookoła wysokie baszty, na których stale wartowali Ukraińcy. W obozie było około pięćdziesięciu gestapowców i strzegących trzystu Ukraińców ${ }^{18}$. Żydów było zawsze ponad tysiąc osób ${ }^{19}$. Byli to przeważnie fachowcy, krawcy, szewcy, stolarze i inni. Część z Nich pracowała dla obozu, a druga na wysyłkę do Niemiec. Rzeczy gotowe układano w skrzynie i wysyłano. Były kompanie leśne, które zajmowały się wycinaniem drzew. Obóz wewnątrz dzielił się na trzy części, które nie miały prawie ze sobą styczności. Obóz pracy, o którym wspominałam, krematorium i obsługa tegoż. Z obozu pracy szła kolejka do krematorium. Miała ona granicę. Zaszedł wypadek, kiedy policjant, popchnąwszy dalej taczkę, został zatrzymany i tegoż jeszcze dnia spalony $^{20}$. Zaznaczyłam, że z Nimi z drugiego obozu prawie się nie miało styczności. Zdarzało się jednak, ponieważ prowiantura znajdowała się po tej stronie, że przychodzili Żydzi po prowiant i wówczas zostawiali ukradkiem listy, w których wszystko opisywali.

Wśród Żydów w obozie byli przeważnie Żydzi polscy, z Lubelszczyzny stu kilkudziesięciu, holenderskich Żydów kilkudziesięciu, kilkunastu francuskich i tyleż belgijskich ${ }^{21}$, niemieckich, czeskich i kilkaset rosyjskich, słowackich, węgierskich $^{22}$. O siódmej rano była zbiórka i wszyscy, śpiewając, szli na swe placówki. Praca nie była o tyle ciężka, ile razy ${ }^{23}$ i to, że robiono to, o czym się nie miało pojęcia. Wewnątrz obozu były baraki dla Żydów, domki komfortowe, urządzone dla niemców, składy na rzeczy z transportów, domki na pracownie. Powietrze

${ }^{16} \mathrm{~W}$ rzeczywistości chodzi prawdopodobnie o obrączkę ślubną jego żony Toby.

${ }^{17}$ Obóz zagłady w Sobiborze był otoczony ogrodzeniem z drutu kolczastego, niepodłączonym jednak do instalacji elektrycznej.

${ }^{18}$ Załoga obozu sobiborskiego składała się z około 30 SS-manów - Niemców i Austriaków, oraz 120-150 strażników, w większości Ukraińców, przeszkolonych w obozie szkoleniowym SS w Trawnikach.

${ }^{19}$ Liczba więźniów żydowskich obsługujących obóz, tzw. Sonderkommando, nigdy nie przekraczała 700 osób.

${ }^{20} \mathrm{~W}$ Sobiborze nie było styczności z tzw. Obozem III, gdzie znajdowały się komory gazowe, stosy spaleniskowe i masowe groby. Nie prowadziła tam kolejka, natomiast na przypominających taczki wózkach więźniowie przewozili ciała osób zmarłych w transportach. Wózki te pozostawiano pod bramą Obozu III, gdzie odbierali je więźniowie pracujący przy grzebaniu i spalaniu zwłok.

${ }^{21}$ Do Sobiboru nie wysyłano żadnych transportów z Belgii.

${ }^{22}$ Najliczniejszą grupę więźniarską w obozie stanowili Żydzi polscy. Żydzi z terenu Związku Sowieckiego, przeważnie jeńcy z Armii Czerwonej, przybyli na krótko przed buntem. Ich wyselekcjonowana grupa liczyła kilkadziesiąt osób. Żydzi słowaccy oraz węgierskojęzyczni przybyli natomiast transportami ze Słowacji.

${ }^{23}$ Chodzi o bicie więźniów pracujących w obozie. 
było zatrute trupim zapachem, wody przez pierwsze dnie pić nie można było z powodu jej trupiego odoru. Poza tym odżywiani byli pierwszorzędnie. Najdroższe artykuły, luksus, przywożone przez transporty zagraniczne, bezpośrednio kierowane na dwór Sobibór, obok tych najwyszukańszych smakołyków zawierały także wszelkie potrzebne zapasy. A zapasów każdy z Nich wiózł na dłuższy okres czasu ${ }^{24}$. Żydzi byli zaopatrywani w to wszystko szczególnie przez swoich magazynierów, lecz nie niemców. Orkiestra grała cały dzień. Cały dzień niemcy przechadzali się, rozglądając się za coraz to inną ofiarą. Dnie leciały. Praca szła naprzód. Rozrastał się obóz. Przybywało baraków. Doskonalili się stolarze w stawianiu domków, studzien (co dwa tygodnie robiono świeżą), szosy. Codziennie ktoś był bity za to, że nie tańczy, za to, że czyta, za to, że się zamyślił. I codziennie kilku zastrzelono, za co? Znajdywali pozory pretekstu, nie siląc się zresztą zanadto na nie. A co kilka dni nadchodziły transporty. Zaczęło się przebąkiwać o powstaniu, o ucieczce. On, zaufany, zapoznawszy się, omówił z pewnym kapitanem marynarki, holendrem, plan ucieczki kilkunastu osób. Lecz nie chcąc przez to narazić wszystkich, postanowili, nic nie mówiąc, urządzić powstanie, by każdy mogąc korzystać z okazji, ratował się na własną rękę. Doszło to jednakże do uszu jednego szewca, któremu jego gestapowiec przyrzekł, że on go zostawi, i gdy ten przyszedł rano, opowiedział mu o wszystkim. Zwołano natychmiast zbiórkę. Wywołało to ogólne przerażenie (takie rzeczy nic dobrego nie wróżyły). Bez wstępu powiedział, że wiedzą o planie zamachu i ucieczce, więc przyznajcie się lepiej, przez co uchronicie cały obóz od przelewu krwi. Serce biło w Nim. Co robić? Wystąpił kapitan. Pytali o wspólników. Lecz nikogo nie zdradził (do spisku należeli jeszcze dwaj holendrzy i dwaj rosjanie). Kazali wystąpić wszystkim holendrom i wszystkich ich wystrzelili na oczach reszty. Ucichła na pewien czas chęć ucieczki i myśl o niej. Dnie płynęły. Niemcy chodzili po obozie, obserwując każdego żyda, Jego zachowanie. Nie wolno było ze sobą zbyt długo rozmawiać, to budziło podejrzenie, nie wolno było myśleć, za to dostawano, musiano tańczyć, śpiewać, zmuszali niemcy do szukania sobie kobiety, ponieważ taki, który Jej nie miał, myślał o tym, co nie trzeba. Jemu też opowiedziano, że niemiec obserwuje Go, widząc, że nie ma nikogo. Mieszkała z nim razem kobieta, która przypadkowo nikogo nie mając, zbliżyła się do Niego ${ }^{25}$. Opadło podejrzenie. Był to płaszczyk, pod którym na nowo można było działać.

W obozie było wiele historii ze złotem. Było ich tyle, taka masa przewijała się przez Ich ręce, że nie chcąc ich oddać w ręce niemców, zakopywali lub zaszywali je. Za złoto groziła kara śmierci. Idąc do lasu, kupowali niektóre artykuły, jak: jajka, ser, kury, płacąc za to 20-to dolarówkami. Jednego razu po rozebraniu transportu

${ }^{24} \mathrm{~W}$ rzeczywistości w obozie więźniowie nie odczuwali głodu tylko wtedy, gdy przyjeżdżały transporty. W przerwach pomiędzy nimi, a takie zdarzały się w Sobiborze często, zdani byli tylko na wyżywienie obozowe, na które składały się głodowe racje chleba, zupy i niesłodzonej namiastki kawy.

${ }^{25}$ Kobiety i mężczyźni mieszkali w obozie w osobnych barakach, ale SS-mani zezwalali im na wieczorne spotkania. 
znaleźli pod ubraniami maleńkie, kilkumiesięczne dziecko. Nie wiedzieli, co z nim zrobić. Lecz nie było rady, gdy dowiedziało się więcej osób: chcecie, byśmy wszyscy przez nie zginęli. Wzięli je więc niemcy z leśnej kompanii i każąc wykopać dołek, siekierą przerąbali je na pół.

Znów pojawiły się plany ucieczki. Różne były plany. Działo się to przed nowym rokiem 1943. Młody chłopak, żyd rosyjski, zgodził się zostać w magazynie odzieży, by gdy niemcy będą ucztowali, podpalić go. Będzie to hasłem do ucieczki i odwróci uwagę niemców od Nich. Zamknięto Go na klucz, pożegnano się z Nim, życzył Im szczęścia, ciesząc się ze swego poświęcenia. Lecz w ostatniej godzinie niemcy, czy dlatego, że byli pod gazem, czy też coś przeczuwając, zaczęli kręcić się pomiędzy barakami. I wtedy widząc, że to teraz się nie uda, On mając klucz otworzył magazyn i wyciagnął stamtąd zrozpaczonego z powodu nieudanej próby chłopca. I tak przeszła jeszcze jedna okazja. W tym czasie nadszedł transport, na który zebrano wszystkich celem wyładowania go. Były tam już tylko trupy, zwapniałe części ciała. Oczyszczali wagon, wyrzucając poszczególne części ciała z osobna. Widok i zapach był straszny. Wszystko było martwe. Cały transport ludzi. Lecz mimo to, a może dlatego niemcy zmusili wtedy wszystkich Żydów do pracy. Wtem usłyszano okrzyk jednego niemca. Był pełen zachwytu. Cóż się stało? Spojrzeli i zmartwiali. Wyrzucali bowiem martwe ciało młodej kobiety z dzieckiem na ręku. Przy wyrzucaniu utrzymało się przy Niej kurczowo. To zastanowiło niemca, który dotknąwszy się dziewczynki, wydał ten okrzyk. Ona żyła. Maleńka, czteroletnia, wyjątkowo śliczna dziewczynka, trzymała się kurczowo swej matki i siedziała cichutko na Jej kolanach, jak gdyby rozumiejąc to wszystko, co się dookoła dzieje. Sfotografowali Ją i języczkiem przybili do ściany ${ }^{26}$. Następny transport to żydzi niemieccy. Po wyjściu z wagonów pozwolono Im paczki zostawić, zebrano w wielkiej sali, gdzie podano Im specjalnie dla Nich przyrządzony obiad ${ }^{27}$, a po nim kierownik obozu przywitał Ich u siebie, we dworze Sobibór, słowami bardzo serdecznymi, mówiąc, że czeka Ich wprawdzie tu praca na roli, ale za to otrzymają odpowiednie, wystarczające Im wyżywienie i czyste baraki. Rozumieją chyba doskonale, że nikt nie będzie Ich traktował jak żydów polskich, którzy rozsiewają jakieś nieprawdopodobne pogłoski o tym, co niemcy robią z żydami i jak Ich traktują. Wprawdzie tamci nie są traktowani jak Oni, ale mimo to, kończy, wiecie przecież, czym są żydzi polscy. Bandą handlarzy, oszustów i wyzyskiwaczy. Po tym dano Im łaskawie możność, zaraz na wstępie, dać znać rodzinie o szczęśliwym przyjeździe w miejsce przeznaczenia. Otrzymali papier i pióra. Każdy też z radością łapał za pióro, by podzielić się z rodziną tym wszystkim i powiedzieć Im, że to, co mówili, to nieprawda. Po zebraniu listów pozwolili Im wykąpać się po podróży. Ubranie mają złożyć,

${ }^{26}$ Historia o martwej matce i żyjącym jeszcze dziecku powtarza się także w relacjach i wspomnieniach innych więźniów ocalonych z Sobiboru, żaden $\mathrm{z}$ nich nie opisuje jednak tak potwornego sposobu zamordowania dziecka. Powtarza się wersja, że zostało ono zastrzelone przez SS-mana.

${ }^{27}$ Nigdy się nie zdarzyło, żeby Żydzi po przybyciu do obozu w Sobiborze dostali jakikolwiek posiłek. 
mówił $[\ldots]^{28}$ tonem, w tym pokoju, a wszystkie wartościowe rzeczy oddać osobno. I wprowadzono Ich do obozu drugiego, którym było krematorium. Takie zdarzyły się kilkakrotnie szopki.

Po kilku dniach nastąpiła inspekcja, w której udział brali Himmler i Frank ${ }^{29}$. Przygotowania przed tym były ogromne. Tresowali żydów, czyścili obóz i tydzień wielkiego zamieszania. Aż przyjechali. Żydom nie wolno się było pokazać ani oglądać Ich. Mieli się zebrać w jednym baraku i nie wysadzać głowy. W związku z tą inspekcją dowiedzieli się historii, którą On niechętnie i kilku tylko osobom opowiedział. Otóż żyd z Obozu II-go ${ }^{30}$ pisał: Jednego razu przybył do nas transport. Czekając na swą kolejkę, zanim puszczono gaz, kobieta rodziła dziecko stojąco. Dziecko wysunęło się i upadło na ziemię. Krwią zalana była przestrzeń wokół tej kobiety. Po zagazowaniu, gdy zabrano wszystkich, wycierali tą krew. Lecz plama, na której leżało dziecko, pozostała. Niemcy bili i denerwowali się, niczym jednak nie dało się tego obmyć. Brali już na koniec benzynę i inne środki, ale to nie schodziło. Zaniepokoiło to kilku niemców, widzących w tym jakiś szczególny znak, lecz ober ich dla uspokojenia zebrał ich i powiedział, że specjalnie dowiadywał się, co to być może. Jeden wielki uczony, chemik, powiedział mu, że jest to tak silny składnik chemiczny, że zejść nie będzie mogło. Przed przyjazdem wielkich gości zmienili te płyty, dając nowe.

Pewnego dnia przywieźli transport samych policjantów żydowskich. Bili ich niemcy więcej jak innych, krzycząc: „Juden fernichten”31.

Decydującym momentem w życiu obozu była chwila, gdy przywieziono transport, nie pozwalając Im zetknąć się z Żydami. Szybko kazali im rozebrać się i zabrali do 2-go obozu. Zastanawiali się, kto Oni mogli być. Lecz segregując ubrania, jeden magazynier znalazł coś dużego, wszytego w marynarce. Rozpruł ją i wyjął list. Był to list od Żyda z Bełżec:

Bracia Żydzi, gdziekolwiek jesteście, pamiętajcie, że pisze do Was żyd z Betżec, z obozu, w którym spalili tyle milionów żydów. Mówią nam, że nas wioza do Niemiec, gdzie otrzymamy wolność i będziemy traktowani jak wszyscy. Ja jednakże w to nie wierzę. Chciatbym, byście moją kartkę znaleźli, przeczytali

${ }^{28} \mathrm{~W}$ oryginalnym tekście brakuje nazwiska SS-mana wygłaszającego przemówienie. Gdy przybywał transport, na rampie w Sobiborze stali zazwyczaj SS-Oberscharführer Gustav Wagner oraz SS-Oberscharführer Karl Frenzel. Natomiast przemówienie mające uspokoić deportowanych do obozu Żydów wygłaszane było najczęściej w Obozie II, gdzie ofiary musiały złożyć swoje bagaże i rozebrać się. Przemówienie takie wygłaszał zwykle SS-Oberscharführer Hermann Michel, nazywany także „Doktorem”, ponieważ w momencie przybycia transportu zakładał biały kitel lekarski (Jules Schelvis, Sobibor. A History of a Nazi Death Camp, Oxford-New York: Berg 2007, s. 61, 70).

${ }^{29}$ Heinrich Himmler odwiedził Sobibór dwukrotnie - w lipcu 1942 i lutym 1943 r. Nigdy natomiast nie wizytował go Hans Frank. Prawdopodobnie drugim dygnitarzem towarzyszącym Himmlerowi był Odilo Globocnik.

${ }^{30} \mathrm{~W}$ rzeczywistości chodzi o Obóz III, gdzie znajdowały się komory gazowe.

${ }^{31}$ Powinno być Juden vernichten - Żydzi zgładzeni. 
i byście nie dali się tak oszukać, jak my. Zróbcie powstanie. Nic nie tracicie. Jeśli się wydostaniecie, to coś zyskacie, jeżeli zabijecie kilku tych bandytów, to też coś zyskacie. W każdym przypadku nic nie tracicie. Uciekajcie więc i spieszcie się, by nie byto za późno ${ }^{32}$.

Mam także list od Żyda z drugiego obozu, który dowiedziawszy się od przywiezionych tego samego dnia, pisze (kartka jest u mnie, przepisuję):

Cu majne chawejrim

Ken zajn az hajnt iz far unz gekumen der tog, wen mir darfn zich cuzamen mit ajch bafrajen fun di blutike hint. Gedenk majne werter. Hot nit mojre. Gajt farojs. Der tojt darf nit zajn far unz szreklech. Kemft majne gute frajnd cuzamen mit di minsker chawejrim. Mir hejbn on un ir helft unz mit wos ir kent.

Frajhajt, 13/X 43 r.

Ojch iz az mir weln zign szojn [...] iz oder ajer ejce [...] ajz wet zajn forlorn weln mir ajne cum cwajtn un ale cuzamen.

(koniec jest zamazany, trudno mi przeczytać33)

(Do moich towarzyszy

Być może dziś nastał dla nas dzień, kiedy powinniśmy się razem z wami uwolnić od tych krwawych psów. Pamiętajcie moje słowa. Nie bójcie się. Idźcie naprzód. Śmierć nie powinna być nam straszna. Walczcie, moi drodzy przyjaciele, razem z towarzyszami z Mińska. My zaczynamy, a wy pomagacie nam, jak tylko możecie.

Wolność, 13 października 1943 r.

Jeśli jest, że już zwyciężymy [...] lub wasza rada [...] zostanie zaprzepaszczona, będziemy jeden $z$ drugim $i$ wszyscy razem) ${ }^{34}$.

Na ten okres przypada urlop lagerführera ${ }^{35}$. Spisek to już zdecydowany i ostateczny. Pod wieczór, gdy zastępca komendanta (nie wszyscy jednak byli wtajemniczeni ze względu na denuncjacje, liczono na ratowanie się każdego na własną rękę) przyszedł do swego krawca przymierzyć szynel, wkładając mu go z tyłu, złapał za nóż i ściął mu głowę. Schował ją pod płaszcze i zdjął z niego pierwszy rewolwer. Tamten nawet okrzyku nie wydał (w obozie nożyka nawet mieć nie wolno było,

${ }^{32}$ Transport więźniów żydowskich ze zlikwidowanego obozu zagłady w Bełżcu został wysłany do Sobiboru 26 VI 1943 r. Miało się w nim znaleźć około 300 osób. Więźniowie Bełżca próbowali się bronić, przeczuwając, że zostali wysłani na śmierć. Niektórzy z nich zbiegli w trakcie transportu, inni stawili opór już na rampie obozowej w Sobiborze (Thomas Toivi Blatt, Sobibór..., s. 88-89).

${ }^{33}$ Pominięto miejsca nieczytelne.

${ }^{34}$ Być może był to fragment odezwy, którą zamierzano odczytać w dniu wybuchu powstania w obozie, na co wskazuje data tego dokumentu - 13 X 1943 r. Właśnie na ten dzień więźniowie pierwotnie zaplanowali wybuch powstania, ale nie doszło do niego z powodu niesprzyjających okoliczności. Dopiero następnego dnia w Sobiborze wybuchł udany bunt więźniów (Jules Schelvis, Sobibor..., s. 154).

${ }^{35}$ Komendantem obozu był wówczas SS-Obersturmführer Franz Reichleitner. 
w związku jednak z planami wszystkie napotkane noże zakopywali, tego dnia je wyjęto). Drugiemu niemcowi, który wszystko węszył, gdy wszedł do stolarza, uderzono go w brzuch, że upadł nieprzytomny i też mu głowę ścięto i wrzucono pod deski i jeszcze pięciu miało taką samą lekką śmierćc ${ }^{36}$. W planie było, by po tym rzucić się na magazyn amunicji i zabrać broń, by bronić się przed niemcami i leśnymi, lecz powstał taki tumult, kobiety zaczęły latać, że spiesząc się, ratowali się na własną rękę. Zabrali broń zamordowanych. Straże ukraińskie zastrzelili z tyłu (te, które stały przy drutach). I zaczęli uciekać. Trupy padały od dotknięcia o drut, od wpadania do dołów, od $\min ^{37}$, lecz nie bacząc na nie, szło się przez trupa, który utorował drogę przez minę, uciekało się do lasu. Nastała okropna panika. Kompania leśna, słysząc strzelaninę, ukraińcy strzelali do żydów, sądzili, że partyzantka napadła na obóz i w popłochu strzelała, rozpraszając się (co żydzi wykorzystali, większość uciekła). Ukraińcy zaś wewnątrz, nie mogąc pojąć strzałów, też je tak zrozumiała, wyobrażali sobie partyzantkę, żydzi bez przerwy strzelali ze swoich paru rewolwerów, licząc słusznie na zamieszanie. I dzięki temu, że brakło gestapo, które zorganizowałoby pościg albo nawet uciszyłoby wrzawę, obóz bez przerwy uciekał. Po drodze zebrało się kilkunastu żydów, postanawiając sobie trzymać się razem, spotkawszy grupę ukraińców, rozbroili Ich, narobili takiego ruchu, że tamci podnieśli momentalnie ręce do góry i później pozwalając Im się poznać, ścięli im głowy. I szli dalej.

Co przeżyli przez tych parę pierwszych dni, idąc tylko przez lasy, nie znając drogi i tylko w nocy, co myśleli, gdy rano słyszeli niedaleko strzelaninę, która na pewno była pościgiem, o tym On zawsze mówił, że trudno Mu jest mi opowiedzieć. Dosyć, że wrócił do swego miasta wraz z małym piętnastoletnim chłopakiem, Majorkiem Zys, i tam przez dwa miesiące na strychu, w kryjówce, później tak się kręcąc na wolności, a na ostatku w partyzantce, doczekał się wyzwolenia. Uciekli z Sobiboru pod koniec 1943 r. Wiele jeszcze niebezpieczeństw i trudu i wiele przejść, zanim to upragnione przyszło. Ale trudno mi o tym pisać. Czyż nie wystarczy, że przyjechał do Lublina w lipcu 1944 r. Spotkaliśmy się i bardzo ucieszyli. Starzy znajomi z dawnych czasów. Znał mnie od dziecka. Opowiadał z żalem o tym, że wyobrażał sobie swe wyzwolenie i historię Sobiboru zupełnie inaczej. „Jak chciałbym, by przynajmniej ogrodzili miejsce, gdzie leżą prochy milionów naszych bliźnich”. Nie mogąc oprzeć się pędowi, pojechał tam. Zobaczył tylko, jak sąsiedzi rozbierają baraki, jak kopią ziemię, szukając i zapewne znajdując złoto ${ }^{38}$. I nie mógł, nie miał już po co

${ }^{36}$ Jules Schelvis podaje, że w czasie powstania w Sobiborze zginęło 12 członków załogi SS i 2 wachmanów. Jeszcze przed wybuchem buntu więźniowie zabili nożami i siekierami 8 Niemców. Nie obcinano im głów, lecz zadawano ciosy (idem, Sobibor..., s. 162-163).

${ }^{37}$ Większość osób zabitych w czasie buntu więźniów zginęła przy ogrodzeniu obozu od strzałów strażników lub na polu minowym.

${ }^{38}$ Już po wyzwoleniu Lubelszczyzny część zabudowań po byłym obozie zagłady została rozebrana przez okoliczną ludność, przeważnie Ukraińców, których w tym czasie wysiedlano na Ukrainę. Oczekiwali oni na dawnej rampie obozowej na transporty, tzw. repatriacyjne, a drewna z rozbieranych baraków używali do rozpalania ognisk. Na terenie byłego obozu 
dochodzić bliżej. Wszystko stanęło jak żywe. „Nie mogę sobie darować, że nikt nie zainteresował się postawieniem tam pomnika, zrobieniem płotu”39. Słyszałam za każdym razem, gdy Go spotkałam, co równało się pogawędce o Sobiborze. „Ci, co tam leżą, nie wyobrażali sobie, że tak mało zwróci się na dwór Sobibór uwagi, myśleli, że ziemia ta będzie obszarem dla Żydów świętym, że ogrodzą i uporządkują wszystko, a dowiaduję się, że służy obecnie jako najurodzajniejsza połać ziemi sianiu pszenicy"40.

W zimie zeszłego roku był nasz ślub. Jako wspomnienie ostatnich dni, byliśmy ze sobą razem tylko pięć tygodni i trzy dni, muszę dodać, że był bardzo szczęśliwy i często mówił, że nie wyobrażał sobie w Sobiborze, że jeszcze w życiu będzie mógł zaznać szczęścia i jeszcze takiego, jak go obecnie przeżywa. Otrzymałam jako podarunek ślubny Jego skarb, z którym miał się nie rozstawać do śmierci, obrączkę ślubną szwagra z Sobiboru, z którą ja nie rozstanę się już nigdy.

Drugiego kwietnia o godzinie przed siódmą wieczór siedzieliśmy w naszym pokoju. Był to ostatni pokój, mieszkaliśmy w sublokatorstwie. Usłyszałam ruch w pokoju gospodarzy. Leżałam na tapczanie, czytając książkę. On coś pisał. Coś mnie tknęło. Powiedziałam tylko „Leon, to oni”. Doszedł do drzwi. Ujął za klamkę. Padł strzał. Jeden strzał przez drzwi. Stał blady. Zerwałam się, nie rozumiejąc. „Uciekajmy drugimi drzwiami” powiedziałam. „Nie mogę”. „Bo co?” „Mam kulę, o tu”. Lecz jeszcze nie chciałam wierzyć, nie mogłam uwierzyć, że to tak, aż tak okropne, niebezpieczne. Ciągnąc Go za rękę, uciekliśmy na ulicę. Złapałam dorożkę. Pojechaliśmy do szpitala. Za kilka godzin operowali. Operacja udała się. Lecz doktorzy ani przez chwilę nie wierzyli w możliwość Jego wyzdrowienia. Nie rozumiałam dlaczego. Męczył się jeszcze przez trzy dni, nie chciałam Mu dawać wody, nie pozwolili. Tak skończył się jeszcze jeden rozdział Sobiboru. Historię tą opowiedziałam za Niego, ja, żona jego, po dziewięciu miesiącach Jego nieobecności. Lecz zdaje się, że On jeszcze żyje i sam opowiada to.

(Dopisek: Jest to zeznanie wdowy po Feldhendlerze, która byta żona jego zaledwie 5-6 tygodni. Ma ona obecnie 20 lat życia)

\section{Słowa kluczowe}

Leon Feldhendler, Żółkiewka, Sobibór

\footnotetext{
Abstract

A testimony written in Lublin in December 1945 by a wife of Leon Feldhendler - one of the two leaders of the uprising in the Sobibor death camp. It describes his

trwały także „wykopki”, dokonywane przez mieszkańców z okolic Sobiboru w poszukiwaniu złota i kosztowności.

${ }^{39}$ Pierwszy pomnik na terenie byłego obozu zagłady postawiony został dopiero w $1965 \mathrm{r}$.

${ }^{40}$ Większość terenu byłego obozu w Sobiborze była po wojnie zarośnięta lasem i nie wykorzystywano go jako pola ornego.
} 
lot during the war and right afterwards - from his being the head of the Żółkiewka Judenrat, through the horror of the Sobibor camp, the uprising, the hiding on the Aryan side and being in a partisan unit, to his being killed by an unknown person in the post-war Lublin.

\section{Key words}

Leon Feldhendler, Żółkiewka, Sobibor 